\title{
Recent advances in the treatment of chronic heart failure
}

\section{[version 1; peer review: 3 approved]}

\author{
Leo F Buckley¹, Amil M Shah (D1,2
}

${ }^{1}$ Department of Pharmacy, Brigham and Women's Hospital, Boston, USA

2Division of Cardiovascular Medicine, Brigham and Women's Hospital, Boston, USA

V1 First published: 20 Dec 2019, 8(F1000 Faculty Rev):2134

https://doi.org/10.12688/f1000research.20447.1

Latest published: 20 Dec 2019, 8(F1000 Faculty Rev):2134

https://doi.org/10.12688/f1000research.20447.1

\section{Abstract}

After more than a decade of relatively modest advancements, heart failure therapeutic development has accelerated, with the PARADIGM$\mathrm{HF}$ trial and the SHIFT trial demonstrated significant reductions in cardiovascular death and heart failure hospitalization for sacubitrilvalsartan and in heart failure hospitalization alone for ivabradine. Several heart failure therapies have since received or stand on the verge of market approval and promise substantive advances in the treatment of chronic heart failure. Some of these improve clinical outcomes, whereas others improve functional or patient-reported outcomes. In light of these rapid advances in the care of adults living with chronic heart failure, in this review we seek to update the general practitioner on novel heart failure therapies. Specifically, we will review recent data on the implementation of sacubitril-valsartan, treatment of functional mitral regurgitation, sodium-glucose cotransporter-2 (SGLT-2) inhibitor therapy, agents for transthyretin amyloid cardiomyopathy, treatment of iron deficiency in heart failure, and the use of biomarkers or remote hemodynamic monitoring to guide heart failure therapy.

\section{Keywords}

heart failure, therapy

\section{Open Peer Review}

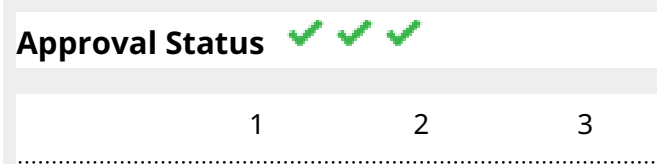

version 1

20 Dec 2019

Faculty Reviews are review articles written by the prestigious Members of Faculty Opinions. The articles are commissioned and peer reviewed before publication to ensure that the final, published version is comprehensive and accessible. The reviewers who approved the final version are listed with their names and affiliations.

1. Ferdinando Iellamo, Research Institute San Raffaele Pisana, Rome, Italy

University of Rome Tor Vergata, Rome, Italy

2. Chim C Lang, University of Dundee, Ninewells Hospital \& Medical School, Dundee, UK

3. Jawahar L Mehta, Central Arkansas Veterans Healthcare System and the University of

Arkansas for Medical Sciences, Arkansas, USA Any comments on the article can be found at the end of the article. 
Corresponding author: Amil M Shah (ashah11@partners.org)

Author roles: Buckley LF: Conceptualization, Writing - Original Draft Preparation; Shah AM: Conceptualization, Supervision, Writing Review \& Editing

Competing interests: AMS has received consulting fees from Philips Ultrasound and Bellerophon Therapeutics and research support from Novartis through Brigham and Women's Hospital. LFB declares that he has no competing interests.

Grant information: The work for this review was supported by an American College of Clinical Pharmacy Foundation New Investigator Award (LFB); National Heart, Lung, and Blood Institute grants R01HL135008 and R01HL143224 (AMS); and a Watkins Discovery Award from the Brigham and Women's Heart and Vascular Center (AMS).

The funders had no role in study design, data collection and analysis, decision to publish, or preparation of the manuscript.

Copyright: $\odot 2019$ Buckley LF and Shah AM. This is an open access article distributed under the terms of the Creative Commons Attribution License, which permits unrestricted use, distribution, and reproduction in any medium, provided the original work is properly cited.

How to cite this article: Buckley LF and Shah AM. Recent advances in the treatment of chronic heart failure [version 1; peer review: 3 approved] F1000Research 2019, 8(F1000 Faculty Rev):2134 https://doi.org/10.12688/f1000research.20447.1

First published: 20 Dec 2019, 8(F1000 Faculty Rev):2134 https://doi.org/10.12688/f1000research.20447.1 


\section{Introduction}

After a decade without successful development of novel heart failure therapeutics, the PARADIGM-HF trial and the SHIFT trial demonstrated significant reductions in cardiovascular death and heart failure hospitalization for sacubitril-valsartan and in heart failure hospitalization alone for ivabradine. Since the market introduction of these two therapies, several heart failure therapies have received or stand on the verge of market approval. In light of the rapid advances in the care of adults living with chronic heart failure, we have sought to update the general practitioner on heart failure therapies approved during this wave of successful drug development.

\section{Implementation of sacubitril-valsartan}

Two clinical trials have tested novel strategies for the safe and effective implementation of sacubitril-valsartan in 498 patients with heart failure and a reduced ejection fraction. The TITRATION study compared the safety and efficacy of conservative and condensed up-titration schedules for sacubitril-valsartan in ambulatory patients ${ }^{1}$. All patients received sacubitril-valsartan 24/26 mg twice daily for 5 days during an open-label, run-in period followed by randomization and two additional treatment periods. At randomization, patients in the conservative arm continued sacubitril-valsartan at 24/26 mg twice daily whereas patients in the condensed arm were titrated to 49/51 mg twice daily. After 2 weeks, the conservative arm increased to $49 / 51 \mathrm{mg}$ twice daily and the condensed arm increased to the maximal dose of $97 / 103 \mathrm{mg}$ twice daily. The condensed arm then continued the maximal 97/103 mg twice daily for the remaining 9 weeks of the study, whereas the conservative arm continued the $49 / 51 \mathrm{mg}$ twice-daily regimen for 3 weeks before increasing to the maximal 97/103 $\mathrm{mg}$ twice daily for 6 weeks. In aggregate, the condensed arm reached the maximal dose with one fewer visit than the conservative arm and increased from $24 / 26 \mathrm{mg}$ to $49 / 51 \mathrm{mg} 2$ weeks earlier than the conservative arm and from $49 / 51 \mathrm{mg}$ to $97 / 103 \mathrm{mg}$ 3 weeks earlier than the conservative arm.

The proportion of patients experiencing any hypotension (9.7\% vs. $8.4 \% ; P=0.57)$ and systolic blood pressure less than $95 \mathrm{~mm} \mathrm{Hg}(8.9 \%$ vs. $5.2 \% ; P=0.10)$ was not significantly different between the conservative and condensed arms. Serum potassium of more than $5.5 \mathrm{mmol} / \mathrm{L}$ occurred in $7.3 \%$ of condensed and $4 \%$ of conservative patients $(P=0.10)$. There was no significant difference in renal dysfunction between the two arms $(7.3 \%$ vs. $7.6 \% ; P=0.99)$. Adverse effects occurred most frequently in patients who switched to sacubitril-valsartan from a low dose of an angiotensin-converting enzyme inhibitor ( $\leq 10 \mathrm{mg}$ of enalapril or equivalent) or angiotensin receptor blocker ( $\leq 160 \mathrm{mg}$ of valsartan or equivalent) and those who had baseline systolic blood pressure of 100 to $110 \mathrm{~mm} \mathrm{Hg}$. Less than one fifth of patients with heart failure reach target doses of renin-angiotensin-aldosterone inhibitors.

The randomized, double-blind PIONEER-HF trial compared in-hospital initiation of sacubitril-valsartan to initiation or enalapril among 881 patients with stabilized decompensated heart failure $^{2}$. Change in N-terminal pro B-type natriuretic peptide
(NT-proBNP) from baseline to week 8 was significantly greater in the sacubitril-valsartan group than the enalapril group (geometric mean ratio vs. baseline: 0.53 for sacubitrilvalsartan vs. 0.75 for enalapril; between-group percent change: $-47 \%$ vs. $-25 \% ; P<0.001)$. Sacubitril-valsartan had no effect on a secondary 7-point composite clinical endpoint but was associated with a reduced risk of rehospitalization for heart failure (35 [8\%] vs. 61 [14\%]; hazard ratio [HR] 0.56, 95\% confidence interval $[\mathrm{CI}] 0.37$ to $0.84 ; P=$ not reported). Of note, the trial protocol aimed to achieve maximal sacubitrilvalsartan doses within 1 week if tolerated. Slightly more patients experienced worsening renal function $(13.6 \%$ vs. $14.7 \%)$, hyperkalemia $(11.6 \%$ vs. $9.3 \%)$, and symptomatic hypotension $(15.0 \%$ vs. $12.7 \%)$ but these differences did not reach statistical significance.

These important trials provide clinicians with structured protocols (Figure 1) to maximize sacubitril-valsartan doses in hemodynamically stable, normokalemic patients with heart failure and a reduced ejection fraction and relatively intact renal function (estimated glomerular filtration rate of at least $30 \mathrm{~mL} / \mathrm{min}$ per $1.73 \mathrm{~m}^{2}$ ).

\section{Sacubitril-valsartan for the treatment of heart failure with preserved ejection fraction}

The PARAGON-HF trial tested the hypothesis that sacubitrilvalsartan lowers the rate of a composite outcome of total heart failure hospitalizations and cardiovascular death compared with valsartan alone in patients with heart failure and preserved ejection fraction ${ }^{3}$. In addition to a left ventricular ejection fraction (LVEF) of at least $45 \%$, patients were required to have additional objective criteria of heart failure, including an elevated natriuretic peptide level, structural heart disease (left atrial enlargement or increased left ventricular wall thickness), and diuretic use. Patients were ineligible if they had a previous LVEF of less than $40 \%$. After a single-blind run-in phase, 4796 patients were randomly assigned to sacubitril-valsartan (target dose of 97/103 mg twice daily) or valsartan (target dose of $160 \mathrm{mg}$ twice daily) and followed for a median of 35 (interquartile range of 30 to 41 ) months.

The number of composite heart failure hospitalizations or cardiovascular deaths was nominally lower in the sacubitrilvalsartan arm than in the valsartan arm (526 vs. 1009; rate ratio $0.87,95 \%$ CI 0.75 to $1.01 ; P=0.06$ ) but did not achieve statistical significance. Randomization to sacubitril-valsartan was associated with a smaller total number of heart failure hospitalizations (690 vs. 797 ; rate ratio $0.85,95 \%$ CI 0.72 to 1.00 ) but no difference in death due to cardiovascular causes (204 [8.5\%] vs. 212 [8.9\%] in the sacubitril-valsartan and valsartan arms respectively) or due to any cause (342 [14.1\%] vs. 349 [14.6\%]). Although New York Heart Association functional class remains unchanged at 8 months in most patients, more sacubitril-valsartan patients than valsartan patients appeared to have investigator-assessed improvements in functional class (347 [15\%] vs. 289 [12.6\%]; $P=$ not reported due to hierarchical analysis plan). Hypotension with systolic blood pressure of less than $100 \mathrm{~mm} \mathrm{Hg}$ and elevations in serum creatinine of at 


\section{Sacubitril-Valsartan Dose Titration Schedules for Ambulatory Patients}

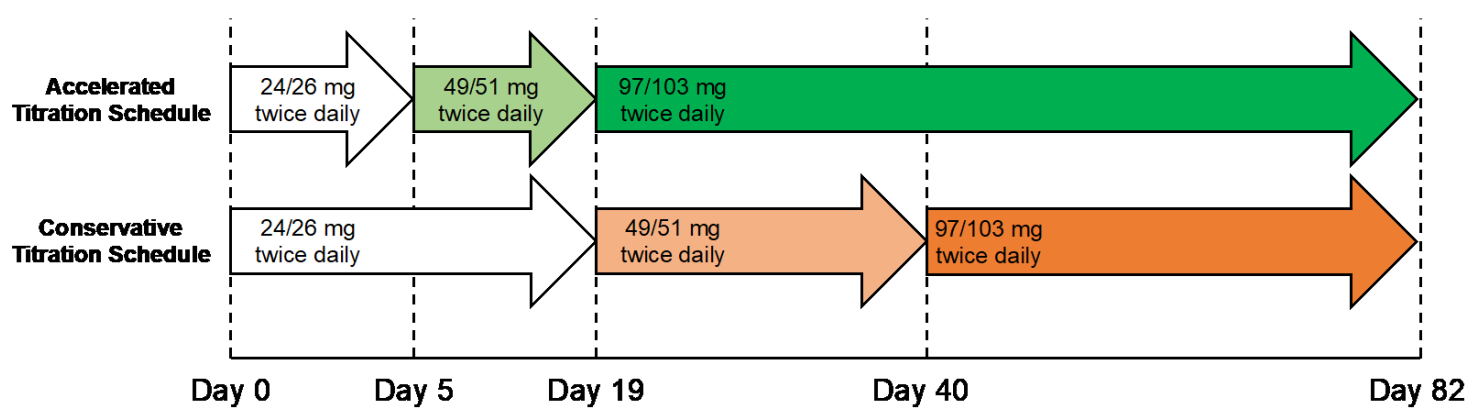

Sacubitril-Valsartan Dose Titration Schedules for Stable, Hospitalized Patients

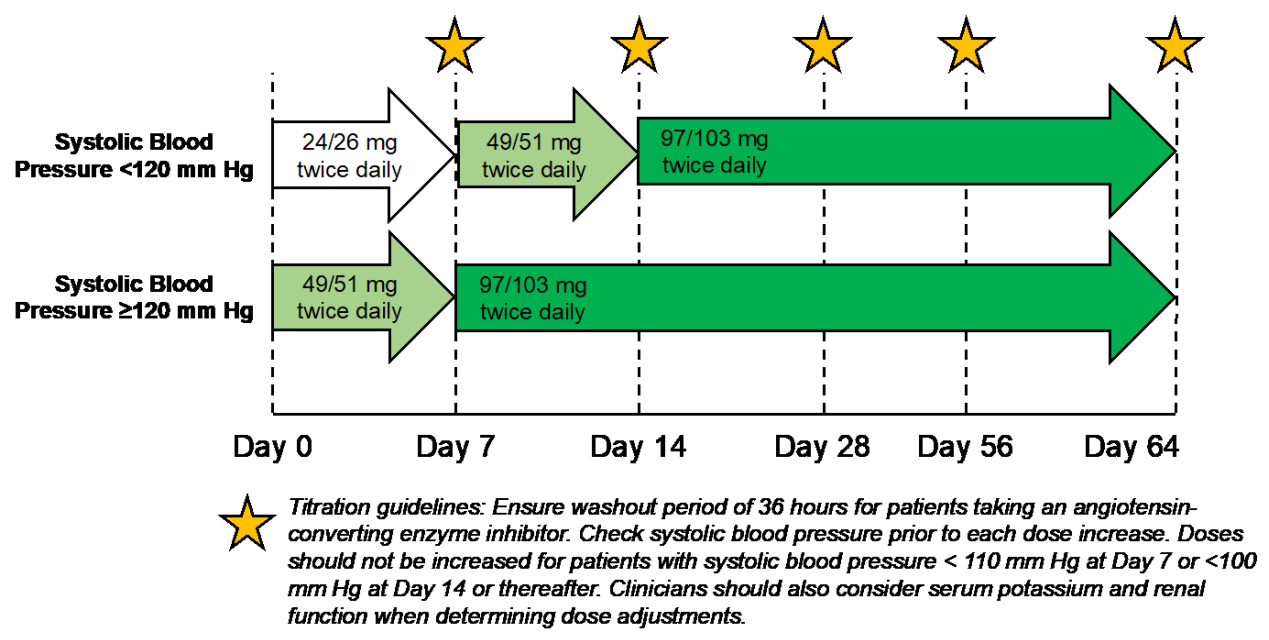

Figure 1. Titration schedules for ambulatory and hospitalized patients initiating sacubitril-valsartan.

least $2.0 \mathrm{mg} / \mathrm{dL}$ occurred less frequently in the sacubitril-valsartan arm, whereas angioedema occurred more frequently in the sacubitril-valsartan arm (14 [0.6\%] vs. $4[0.2 \%], P=0.02)$. The investigators concluded that sacubitril-valsartan did not reduce the rate of a composite outcome of total heart failure hospitalizations and cardiovascular deaths compared with valsartan in patients with heart failure and preserved ejection fraction. Furthermore, any potential beneficial treatment effect appeared restricted to heart failure hospitalization and not cardiovascular mortality. The use of valsartan as an active comparator was consistent with most participants' pre-enrollment treatment regimens but may have diminished any potential betweengroup differences.

In pre-specified subgroup analyses, significant heterogeneity of effect was observed by qualifying LVEF and gender. Sacubitril-valsartan reduced the primary composite outcome in patients with an ejection fraction below the median of $57 \%$ (rate ratio $0.78,95 \%$ CI 0.64 to 0.95 ) but not those with an ejection fraction above the median of $57 \%$ (rate ratio $1.00,95 \% \mathrm{CI} 0.81$ to 1.23 ) and among women (rate ratio $0.73,95 \%$ CI 0.59 to 0.90 ) but not men (rate ratio $1.03,95 \%$
CI 0.85 to 1.25 ). Although the results of pre-specified subgroup analyses in an overall neutral trial must be considered with caution, the intriguing interactions by LVEF and gender may prove to be significant for several reasons. Patients who have a preserved but modestly depressed ejection fraction may be phenotypically more similar to those with a markedly reduced than robustly preserved ejection fraction ${ }^{4}$. Sacubitril-valsartan has proven benefits in patients with an ejection fraction of less than $40 \%$. Moreover, post-hoc analyses of spironolactone ${ }^{6}$ and candesartan ${ }^{7}$ clinical trials suggest a benefit for these therapies in patients with a mid-range ejection fraction. The effect modification of gender merits further research. Although this unexpected finding may be attributable to chance, the known biological differences between men and women provide multiple potential explanations for future investigation. In addressing one question, PARAGON-HF has not only advanced our understanding of heart failure with preserved ejection fraction but also highlighted several areas for future research. It will be interesting to see whether guidelines incorporate the results of PARAGON-HF in a manner consistent with TOPCAT, as American guidelines give spironolactone a IIb recommendation for decreasing hospitalizations ${ }^{8}$. 


\section{Treatment of secondary mitral regurgitation}

Although secondary mitral regurgitation due to left ventricular dysfunction confers an increased risk of hospitalization and death, treatment options remain limited as surgical repair or replacement does not improve clinical outcomes ${ }^{9,10}$. The MitraClip is a percutaneous device that reduces mitral regurgitation severity by facilitating approximation of the anterior and posterior mitral valve leaflets ${ }^{11}$. The efficacy and safety of mitral valve repair with the MitraClip were studied in two clinical trials with similar designs.

MITRA-FR $(\mathrm{N}=304)$ and COAPT $(\mathrm{N}=614)$ were randomized comparisons of mitral valve repair with the MitraClip plus guideline-directed medical therapy versus guideline-directed medical therapy alone ${ }^{12,13}$. Although both trials enrolled patients with at least moderate to severe regurgitation, COAPT targeted a population of patients with a larger effective orifice regurgitant area ( $\geq 30$ vs. $\geq 20 \mathrm{~mm}^{2}$ ) or a larger regurgitant volume $(>45$ vs. $>30 \mathrm{~mL}$ ) and less severe left ventricular dysfunction (LVEF 20 to $50 \%$ vs. 15 to $40 \%$ and left ventricular end-systolic diameter of not more than $70 \mathrm{~mL}$ in COAPT vs. no restriction in MITRA-FR). Thus, the contribution of mitral regurgitation to heart failure symptoms relative to myocardial dysfunction may have been greater in COAPT than MITRAFR. In addition, COAPT patients were enrolled after optimization of guideline-directed medical therapy.

In MITRA-FR, mitral valve repair with the MitraClip had no significant effect on the primary endpoint of all-cause death or heart failure hospitalization at 12 months $(54.6 \%$ vs. $51.3 \%$ for repair vs. usual care; HR $1.16,95 \%$ CI 0.73 to $1.83 ; P=0.53$ ). In contrast, in the COAPT trial, mitral valve repair with the MitraClip significantly reduced the risk of the primary endpoint of heart failure hospitalization at 24 months $(35.8 \%$ vs. $67.9 \%$; HR $0.53,95 \%$ CI 0.40 to $0.70 ; P<0.001)$ and the composite of all-cause death or heart failure hospitalization $(P<0.001)$.

Pharmacologic treatment with sacubitril-valsartan may also reduce mitral valve regurgitation, although the effects on clinical outcomes remain unclear. In the PRIME trial, patients with heart failure and mitral valve regurgitation who were randomly assigned to sacubitril-valsartan had significantly greater reductions in effective orifice regurgitant area $\left(-0.06 \pm 0.10\right.$ vs. $\left.-0.02 \pm 0.10 \mathrm{~cm}^{2} ; P=0.03\right)$ and regurgitant volume $(-4.3 \pm 15.1$ vs. $-11.6 \pm 14.4 \mathrm{~mL} ; P=0.009)$ than those randomly assigned to valsartan. One $(2 \%)$ death and three $(5 \%)$ heart failure events occurred in the sacubitril-valsartan group versus zero and five $(9 \%)$ in the valsartan group $(P>0.49$ for each).

\section{SGLT-2 inhibitors and heart failure}

The risk of incident heart failure in patients with type 2 diabetes mellitus (T2DM) is twofold greater than that of patients without $\mathrm{T}_{2} \mathrm{DM}^{14}$. Moreover, the presence of $\mathrm{T} 2 \mathrm{DM}$ is associated with a poor prognosis among patients with heart failure ${ }^{14}$.

About $90 \%$ of tubular glucose reabsorption occurs through the tubular sodium-glucose co-transporter-2 (SGLT-2) $)^{15}$. SGLT-2 inhibitors therefore lower blood glucose concentrations by enhancing glucosuria. SGLT-2 inhibition also induces durable weight loss (primarily a reduction in fat mass and not in lean mass) and lowers blood pressure ${ }^{16}$.

Secondary and post-hoc analyses of three clinical trials provide strong evidence that SGLT-2 inhibitors modulate heart failure outcomes in patients with T2DM. Three SGLT-2 inhibitors (empagliflozin, canagliflozin, and dapagliflozin) significantly reduce the composite of heart failure hospitalization or cardiovascular death ${ }^{17-19}$. Whereas the beneficial effects of empagliflozin were consistent between patients with and without a history of heart failure at baseline ${ }^{20}$, canagliflozin and dapagliflozin demonstrated larger effect sizes in patients with a history of heart failure ${ }^{21-23}$.

Small observational studies suggest that treatment of T2DM (with or without heart failure) with SGLT-2 inhibitors improves left ventricular filling pressure, as measured by E/e' ratio and left atrial volume index ${ }^{24,25}$. The molecular mechanisms through which SGLT-2 inhibition may modulate cardiac structure and function remain under investigation. Hypothesized mechanisms include altered myocardial metabolism and energetics, glucosuria-induced diuresis without concomitant renin-angiotensin-aldosterone system activation, and inhibition of the myocardial sodium-hydrogen transporter $^{10}$.

Most recently, the DAPA-HF trial extended the benefits of SGLT-2 inhibitors from patients with T2DM to heart failure with reduced LVEF patients without $\mathrm{T}_{2} \mathrm{DM}^{26}$. This trial randomly assigned 4744 patients with symptomatic heart failure and an ejection fraction of less than $40 \%$ to receive dapagliflozin $10 \mathrm{mg}$ once daily or placebo, in addition to background heart failure therapy. The primary endpoint was hospitalization or urgent visit for heart failure or cardiovascular death. Most patients $(58 \%)$ did not have a history of diabetes mellitus at baseline. The mean LVEF and the median NT-proBNP level at baseline were approximately $31 \pm 7 \%$ and 1400 (857 to 2650) $\mathrm{pg} / \mathrm{mL}$, respectively. Use of guideline-directed medical therapy was high, including angiotensin-converting enzyme inhibitor (56\%), angiotensin receptor blocker (27\%) or sacubitril-valsartan (11\%), a beta-blocker (96\%), and mineralocorticoid receptor antagonist $(71 \%)$.

After a median follow-up duration of 18.2 months, patients randomly assigned to dapagliflozin experienced significantly fewer primary composite events than those randomly assigned to placebo ( $16.3 \%$ vs. $21.2 \%$; HR $0.74,95 \%$ CI 0.65 to 0.85 ; $P<0.001)$. Dapagliflozin also reduced the incidence of each of the individual components of the primary outcome. Furthermore, the benefits of dapagliflozin did not significantly differ between patients with (HR $0.75,95 \%$ CI 0.63 to 0.90 ) and without (HR $0.73,95 \%$ CI 0.60 to 0.88 ) T2DM at baseline $(P$ interaction $=$ not reported $)$. As expected, hypoglycemia requiring intervention occurred infrequently (4/2368 [0.2\%]) in the dapagliflozin arm. There were no significant differences in amputations, diabetic ketoacidosis, or renal adverse events. These exciting results have re-positioned SGLT-2 inhibitors as a complete cardiometabolic, rather than glucose-lowering, therapy. 


\section{Transthyretin amyloid cardiomyopathy}

Aggregation of misfolded transthyretin monomers into amyloid fibrils and subsequent tissue deposition lead to tissue dysfunction $^{27}$. Myocardial infiltration of amyloid fibrils can cause heart failure by interfering with cardiac contractility and relaxation as well as through direct toxicity of the amyloid fibrils. Transthyretin amyloid cardiomyopathy may represent up to $12 \%$ of all cases of heart failure with preserved ejection fraction $^{28}$. Until the development of transthyretin stabilizers and RNA therapeutics, transthyretin amyloid cardiomyopathy treatment focused on symptom palliation and there was minimal impetus to diagnose this debilitating condition.

\section{Tafamidis}

Tafamidis is a synthetic small molecule that binds to the thyroxine-binding sites on transthyretin ${ }^{29}$. In adults with either wild-type or hereditary transthyretin amyloid cardiomyopathy, tafamidis significantly reduced the risk of all-cause mortality and cardiovascular hospitalization in the randomized, double-blind, placebo-controlled ATTR-ACT study ${ }^{30}$. Of the 441 patients of ATTR-ACT, 71\% $(\mathrm{n}=186)$ of tafamidis patients were living compared with $57 \%(\mathrm{n}=101)$ of placebo patients at 32 months (win ratio 1.70, 95\% CI 1.26 to 2.29; $P<0.001)$. Cardiovascular hospitalization occurred in 138 tafamidis patients $(52 \%$; 0.48 per patient-year) compared with 107 placebo patients (61\%; 0.70 per patient-year) (relative risk ratio $0.68,95 \%$ CI 0.56 to $0.81 ; P=$ not reported).

The effects of tafamidis were consistent across transthyretin genotypes (for those with hereditary transthyretin amyloid cardiomyopathy) and both the $80 \mathrm{mg}$ and $20 \mathrm{mg}$ tafamidis doses. Delayed worsening heart failure symptoms and declining exercise capacity were observed in the tafamidis arms as early as 6 months, whereas the mortality benefit emerged after 18 months. ATTR-ACT was not powered to detect statistically significant improvements in left ventricular structure and function, although favorable trends were observed in left ventricular wall thickness and left ventricular global longitudinal strain. The incidence of serious adverse events was not significantly different between tafamidis and placebo.

\section{Patisiran}

Patisiran is a small, interfering $\mathrm{RNA}^{31}$ encapsulated within a liposome that targets a conserved sequence in the $3^{\prime}$ untranslated region of wild-type and mutant transthyretin mRNA, thereby suppressing gene expression via the RNA-induced silencing complex ${ }^{32}$. Patisiran $0.3 \mathrm{mg} / \mathrm{kg}$ every 3 weeks decreased serum transthyretin levels by $81 \%$ and improved neuropathy, as measured by the modified Neuropathy Impairment Score +7 in 225 patients with hereditary transthyretin amyloidosis enrolled in the randomized, double-blind, placebocontrolled APOLLO study $(\mathrm{N}=225)^{33}$.

Transthoracic two-dimensional echocardiography was performed in $126(56 \%)$ APOLLO patients with left ventricular wall thickness of at least $13 \mathrm{~mm}$ and no history of aortic valve disease or hypertension ${ }^{34,35}$. Mean left ventricular wall thickness (least squares mean difference $[\mathrm{LSMD}] \pm$ standard error of the mean $[\mathrm{SEM}],-0.9 \pm 0.4 ; P=0.017)$ and left ventricular enddiastolic volume $(\mathrm{LSEM} \pm \mathrm{SEM},-5.1 \pm 1.9$ vs. $-13.4 \pm 3.4$;
$P=0.036)$ each decreased to a greater extent in the patisiran arm compared with placebo at 18 months. Patisiran improved left ventricular absolute global longitudinal strain by $1.4 \%(95 \%$ CI 0.3 to $0.5 \% ; P=0.02)$ versus placebo. Absolute basal, midwall and apical longitudinal strains also improved with patisiran treatment with basal longitudinal strain reaching statistical significance. In an exploratory post-hoc analysis of clinical outcomes, patisiran was associated with a trend toward lower risk of cardiac death or hospitalization compared with placebo (10.1 vs. 18.7 events per 100 patient-years; HR $0.54,95 \%$ CI 0.28 to 1.01$)$.

\section{Clinical implementation}

Tafamidis was approved by the US Food and Drug Administration for the treatment of wild-type or hereditary transthyretin-mediated amyloid cardiomyopathy in 2019, whereas patisiran was approved for the treatment of hereditary transthyretin amyloid polyneuropathy, but not amyloid cardiomyopathy, in 2018. Both agents have a considerable cost of tens or hundreds of thousands of dollars annually. Thus, patisiran is unlikely to be covered by payers for the treatment of amyloid cardiomyopathy and tafamidis is unlikely to be covered for the treatment of polyneuropathy. Tafamidis is the preferred agent for patients with amyloid cardiomyopathy.

The effects of a second RNA therapeutic, inotersen ${ }^{36}$, and a second transthyretin tetramer stabilizer, $\mathrm{AG} 10^{37}$, on cardiac structure and function in adults with transthyretin amyloid cardiomyopathy are unclear.

\section{Iron deficiency}

Depending upon the definition, iron deficiency (with or without anemia) affects up to $50 \%$ of adults with chronic heart failure $^{38-40}$ and is associated with poor prognosis ${ }^{41}$, impaired exercise capacity and skeletal muscle function ${ }^{42,43}$, and worse quality of life ${ }^{44}$. Patients with heart failure have decreased myocardial iron content $^{45}$, and iron-deficient cardiomyocytes have impaired contractility ${ }^{46}$ and mitochondrial dysfunction ${ }^{47,48}$. Iron repletion with intravenous iron improves quality of life and may prevent heart failure hospitalizations in patients with heart failure and iron deficiency, irrespective of anemia status ${ }^{49,50}$. In 2017, three clinical trials addressed important unanswered questions related to iron repletion in adults with heart failure, namely the effect of iron repletion on exercise capacity as measured by peak oxygen consumption ${ }^{50}$, the effect of iron repletion on peripheral skeletal muscle function ${ }^{51}$, and the role of oral iron supplements in patients with heart failure and iron deficiency ${ }^{52}$.

\section{Effect of ferric carboxymaltose on exercise capacity in patients with iron deficiency and chronic heart failure (EFFECT-HF)}

EFFECT-HF randomly assigned 172 adults with symptomatic heart failure with reduced ejection fraction and iron deficiency (defined as serum ferritin of less than $100 \mathrm{ng} / \mathrm{mL}$ or serum ferritin 100 to $300 \mathrm{ng} / \mathrm{mL}$ with a transferrin saturation of less than 20\%) to receive ferric carboxymaltose, dose-adjusted to target hemoglobin, ferritin, and transferrin saturation levels, or usual care for 24 weeks ${ }^{49}$. At 24 weeks, peak oxygen consumption decreased to a greater extent in the usual 
care arm than the ferric carboxymaltose arm (LSMD \pm SEM, $\left.1.0 \pm 0.4 \mathrm{~mL} \cdot \mathrm{kg}^{-1} \cdot \mathrm{min}^{-1} ; P=0.02\right)$. There were no betweengroup differences in ventilatory efficiency, as measured by the slope of the carbon dioxide-minute ventilation relationship, or treatment effect differences between patients with and without concomitant anemia.

Thus, EFFECT-HF was the first trial to demonstrate an improvement in exercise capacity using gas-exchange variables rather than the 6-minute walk test. In their joint 2017 focused update of the Guideline for the Management of Heart Failure, the American College of Cardiology Foundation and the American Heart Association gave intravenous iron replacement to improve function status and quality of life a weak recommendation (IIb) based upon moderate-quality evidence (B-R $)^{8}$. EFFECT-HF was not included in the focused guideline update.

\section{Ferric iron in heart failure II (FERRIC-HF II)}

FERRIC-HF was a randomized, double-blind, placebo-controlled clinical trial of 40 patients with symptomatic heart failure with reduced ejection fraction, iron deficiency (defined as serum ferritin of less than $100 \mathrm{ng} / \mathrm{mL}$ or serum ferritin 100 to $300 \mathrm{ng} / \mathrm{mL}$ with a transferrin saturation of less than 20\%), and normal folate and vitamin $\mathrm{B}_{12}$ levels ${ }^{51}$. Patients randomly received iron isomaltoside (the total dose was calculated by using the Ganzoni formula) or matching placebo. The primary endpoint was phosphocreatine recovery half-time on dynamic 31P magnetic resonance spectroscopy during submaximal exercise, where a shorter half-life indicates faster phosphocreatine recovery and improved mitochondrial oxidative function.

At 2 weeks, phosphocreatine half-time was -6.8 seconds (95\% CI -11.5 to $-2.1 ; P=0.006$ ) shorter in the iron isomaltoside group than the placebo group. Iron isomaltoside also improved adenosine diphosphate recovery half-time but had no effect on resting or end-exercise phosphocreatine or adenosine diphosphate half-time. This study provides important mechanistic insight into the pleiotropic effects of iron repletion in heart failure.
Iron repletion effects on oxygen uptake in heart failure (IRONOUT HF)

In IRONOUT HF, 225 patients with symptomatic heart failure with reduced ejection fraction and iron deficiency (defined as serum ferritin of less than $100 \mathrm{ng} / \mathrm{mL}$ or serum ferritin 100 to $300 \mathrm{ng} / \mathrm{mL}$ with a transferrin saturation of less than 20\%) were randomly assigned to receive iron polysaccharide $150 \mathrm{mg}$ twice daily for 16 weeks $^{52}$. Oral iron supplementation with iron polysaccharide had no effect on peak oxygen consumption, ventilatory efficiency, 6-minute walk distance, or heart failure symptoms. Notably, iron polysaccharide had minimal effects on serum ferritin (median change from baseline of $18 \mathrm{ng} / \mathrm{mL}, 95 \% \mathrm{CI}-8$ to 38 ) and transferrin saturation (median change from baseline of $2 \%, 95 \%$ CI -3 to $7 \%$ ). Figure 2 compares changes in serum ferritin and transferrin saturation between oral and intravenous iron repletion regimens in patients with heart failure at multiple time points. Subgroup analyses suggest that iron repletion was greater among patients with lower levels of hepcidin, an iron regulatory protein that decreases enteral iron absorption and sequesters iron intracellularly.

Future studies should determine whether different oral iron regimens can replete iron stores in patients with heart failure. Studies of women with anemia suggest that frequent oral iron administration induces an increase in hepcidin levels and that less frequent oral supplementation (for example, once daily on three days of the week) paradoxically may improve iron repletion ${ }^{52,53}$.

\section{Biomarker-guided heart failure therapy}

The natriuretic peptide B-type natriuretic peptide (BNP) and its congener N-terminal-proBNP (NT-proBNP) provide considerable diagnostic and prognostic value in heart failure ${ }^{19}$. Yet the value of natriuretic peptide-guided heart failure management remains unclear. A meta-analysis of 2000 participants across 11 clinical trials demonstrated significant reductions in all-cause mortality (HR $0.62,95 \% \quad \mathrm{CI} \quad 0.45$ to 0.86 ; $P=0.004$ ), heart failure hospitalization (HR 0.80, 95\%

\section{Serum Ferritin}

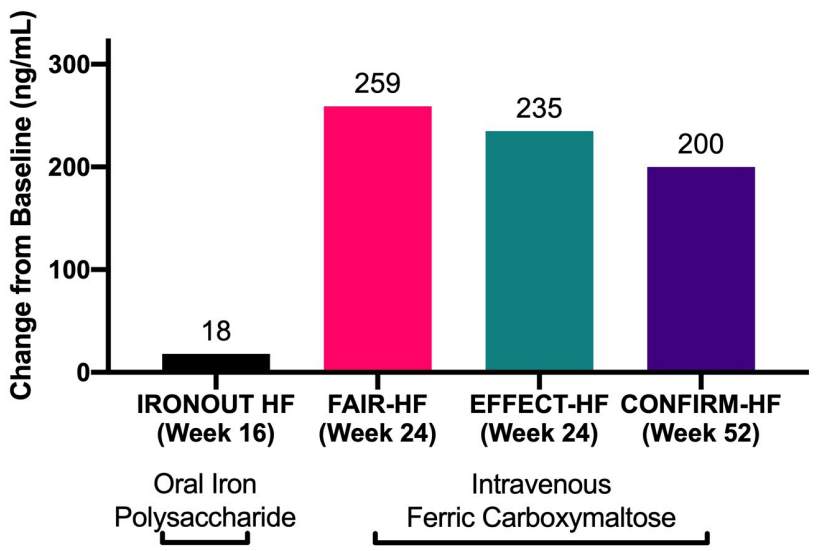

Transferrin Saturation

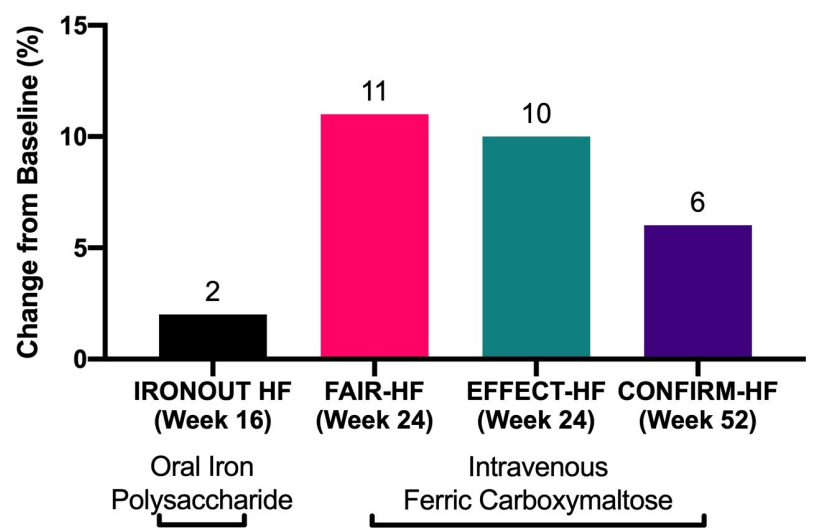

Figure 2. Comparison of iron repletion regimens in patients with heart failure. 
CI 0.67 to $0.94 ; P=0.009)$, and cardiovascular hospitalization (HR $0.82,95 \%$ CI 0.67 to $0.99 ; P=0.048$ ) with natriuretic peptide-guided heart failure management ${ }^{54}$. In contrast, the GUIDE-IT trial $(\mathrm{N}=894)$ found no difference in time to first heart failure hospitalization or cardiovascular death between patients randomly assigned to an NT-proBNP-guided strategy and usual care ${ }^{55}$.

An exploratory, post-hoc analysis of the neutral TIME-CHF trial used the gap-time method to compare NT-proBNP-guided therapy with usual care to account for recurrent events ${ }^{56}$. While NT-proBNP-guided therapy was associated with reduced second all-cause hospitalizations, there was no effect on the second heart failure hospitalization. In the subgroup of patients younger than 75 years, guided therapy was associated with reduced first and second all-cause and heart failure hospitalizations. Current guidelines do not recommend natriuretic peptide-guided therapy ${ }^{57,58}$.

Carbohydrate antigen 125 is a glycoprotein associated with prognosis in acute heart failure. In a multicenter clinical trial of 380 patients, carbohydrate antigen 125-guided therapy significantly reduced the composite of death or heart failure hospitalization at 1 year. Replication of these results would provide compelling support for carbohydrate antigen 125-guided therapy.

\section{Remote hemodynamic monitoring-guided heart failure therapy}

Titration of guideline-recommended medical therapy to a target pulmonary artery diastolic pressure, estimated using an implantable hemodynamic monitor, reduces heart failure hospitalizations by $28 \%$ in patients with reduced and preserved ejection fraction ${ }^{59,60}$. Recent analyses have provided additional insights into the efficacy and safety of remote hemodynamic monitoring. First, the findings of the CHAMPION trial have been replicated in two separate analysis of routinely collected clinical data ${ }^{61,62}$. Second, review of medication titration patterns during the CHAMPION trial has demonstrated that diuretic adjustments and (among patients with heart failure and a reduced ejection fraction) guideline-directed medical therapy adjustments contributed to the reduced hospitalization rates ${ }^{63,64}$. Third, individual practices have begun to report their experience with the implementation and maintenance of a remote hemodynamic monitoring program ${ }^{65-67}$. These practice-based insights will prove useful as additional remote monitoring devices reach the market. Last, comparative effectiveness studies suggest that remote hemodynamic monitoring meets currently accepted thresholds for cost-effectiveness but the overall budget impact may be difficult to absorb ${ }^{68,69}$. Ongoing research is investigating the role of remote hemodynamic monitoring in patients with mechanical circulatory support devices and the effects of novel heart failure therapies on pulmonary artery pressure p0-72 $^{7}$.

\section{Conclusions}

After more than a decade of relatively modest advancements, heart failure therapeutic development has accelerated and led to several advances in the treatment of chronic heart failure. Some of these new technologies improved clinical outcomes, whereas others improve functional or patient-reported outcomes.
1. Senni M, McMurray JJ, Wachter R, et al.: Initiating sacubitril/valsartan (LCZ696) in heart failure: results of TITRATION, a double-blind, randomized comparison of two uptitration regimens. Eur J Heart Fail. 2016; 18(9): 1193-202. PubMed Abstract | Publisher Full Text | Free Full Text

2. F Velazquez EJ, Morrow DA, DeVore AD, et al:: Angiotensin-Neprilysin Inhibition in Acute Decompensated Heart Failure. N Engl J Med. 2019; 380(6): 539-548. PubMed Abstract | Publisher Full Text | F1000 Recommendation

3. F Solomon SD, McMurray JJV, Anand IS, et al.: Angiotensin-Neprilysin Inhibition in Heart Failure with Preserved Ejection Fraction. N Engl J Med. 2019; 381(17): 1609-1620.

PubMed Abstract | Publisher Full Text | F1000 Recommendation

4. Hsu JJ, Ziaeian B, Fonarow GC: Heart Failure With Mid-Range (Borderline) Ejection Fraction: Clinical Implications and Future Directions. JACC Heart Fail. 2017; 5(11): 763-771.

PubMed Abstract | Publisher Full Text | Free Full Text

5. McMurray JJ, Packer M, Desai AS, et al.: Angiotensin-neprilysin inhibition versus enalapril in heart failure. N Engl J Med. 2014; 371(11): 993-1004. PubMed Abstract | Publisher Full Text

6. F Solomon SD, Claggett B, Lewis EF, et al:: Influence of ejection fraction on outcomes and efficacy of spironolactone in patients with heart failure with preserved ejection fraction. Eur Heart J. 2016; 37(5): 455-62. PubMed Abstract | Publisher Full Text | Free Full Text | F1000 Recommendation

7. Lund $\mathrm{LH}$, Claggett $\mathrm{B}$, Liu J, et al:: Heart failure with mid-range ejection fraction in CHARM: characteristics, outcomes and effect of candesartan across the entire ejection fraction spectrum. Eur J Heart Fail. 2018; 20(8): 1230-1239. PubMed Abstract | Publisher Full Text

8. Yancy CW, Jessup M, Bozkurt B, et al:: 2017 ACC/AHA/HFSA Focused Update of the 2013 ACCF/AHA Guideline for the Management of Heart Failure: A Report of the American College of Cardiology/American Heart Association Task Force on Clinical Practice Guidelines and the Heart Failure Society of America. J Am Coll Cardiol. 2017; 70(6): 776-803.

PubMed Abstract | Publisher Full Text

9. Asgar AW, Mack MJ, Stone GW: Secondary mitral regurgitation in heart failure: pathophysiology, prognosis, and therapeutic considerations. J Am Coll Cardiol. 2015; 65(12): 1231-1248.

PubMed Abstract | Publisher Full Text

10. Nishimura RA, Otto CM, Bonow RO, et al:: 2017 AHA/ACC Focused Update of the 2014 AHA/ACC Guideline for the Management of Patients With Valvular Heart Disease: A Report of the American College of Cardiology/American Heart Association Task Force on Clinical Practice Guidelines. J Am Coll Cardiol. 2017; 70(2): 252-289

PubMed Abstract | Publisher Full Text

11. F Feldman T, Foster E, Glower DD, et al:: Percutaneous repair or surgery for mitral regurgitation. N Engl J Med. 2011; 364(15): 1395-406. PubMed Abstract | Publisher Full Text | F1000 Recommendation

12. F Obadia JF, Messika-Zeitoun D, Leurent G, et al:: Percutaneous Repair or Medical Treatment for Secondary Mitral Regurgitation. N Engl J Med. 2018; 379(24): 2297-2306.

PubMed Abstract | Publisher Full Text | F1000 Recommendation

13. F Stone GW, Lindenfeld J, Abraham WT, et al.: Transcatheter Mitral-Valve Repair in Patients with Heart Failure. N Engl J Med. 2018; 379(24): 2307-2318. PubMed Abstract | Publisher Full Text | F1000 Recommendation

14. Dunlay SM, Givertz MM, Aguilar D, et al.: Type 2 Diabetes Mellitus and Heart Failure, A Scientific Statement From the American Heart Association and Heart Failure Society of America. J Card Fail. 2019; 25(8): 584-619. PubMed Abstract | Publisher Full Text 
15. DeFronzo RA, Norton L, Abdul-Ghani M: Renal, metabolic and cardiovascular considerations of SGLT2 inhibition. Nat Rev Nephrol. 2017; 13(1): 11-26. PubMed Abstract | Publisher Full Text

16. Carbone S, Dixon DL, Buckley LF, et al:: Glucose-Lowering Therapies for Cardiovascular Risk Reduction in Type 2 Diabetes Mellitus: State-of-the-Art Review. Mayo Clin Proc. 2018; 93(11): 1629-1647. PubMed Abstract | Publisher Full Text | Free Full Text

17. F Zinman B, Wanner C, Lachin JM, et al.: Empagliflozin, Cardiovascular Outcomes, and Mortality in Type 2 Diabetes. N Engl J Med. 2015; 373(22): 2117-28.

PubMed Abstract | Publisher Full Text | F1000 Recommendation

18. F Neal B, Perkovic V, Mahaffey KW, et al:: Canagliflozin and Cardiovascula and Renal Events in Type 2 Diabetes. N Engl J Med. 2017; 377(7): 644-657. PubMed Abstract | Publisher Full Text | F1000 Recommendation

19. F Wiviott SD, Raz I, Bonaca MP, et al:: Dapagliflozin and Cardiovascular Outcomes in Type 2 Diabetes. N Engl J Med. 2019; 380(4): 347-357. PubMed Abstract | Publisher Full Text | F1000 Recommendation

20. F Fitchett D, Zinman B, Wanner C, et al:: Heart failure outcomes with empagliflozin in patients with type 2 diabetes at high cardiovascular risk results of the EMPA-REG OUTCOME $囚$ trial. Eur Heart J. 2016; 37(19): 1526-34. PubMed Abstract | Publisher Full Text | Free Full Text | F1000 Recommendation

21. Rådholm K, Figtree G, Perkovic V, et al.: Canagliflozin and Heart Failure in Type 2 Diabetes Mellitus. Circulation. 2018; 138(5): 458-468. PubMed Abstract | Publisher Full Text | Free Full Text

22. F Figtree GA, Rådholm K, Barrett TD, et al.: Effects of Canagliflozin on Heart Failure Outcomes Associated With Preserved and Reduced Ejection Fraction in Type 2 Diabetes Mellitus. Circulation. 2019; 139(22): 2591-2593. PubMed Abstract | Publisher Full Text | F1000 Recommendation

23. F Kato ET, Silverman MG, Mosenzon O, et al.: Effect of Dapagliflozin on Heart Failure and Mortality in Type 2 Diabetes Mellitus. Circulation. 2019; 139(22): 2528-2536.

PubMed Abstract | Publisher Full Text | F1000 Recommendation

24. Soga F, Tanaka H, Tatsumi K, et al:: Impact of dapagliflozin on left ventricular diastolic function of patients with type 2 diabetic mellitus with chronic heart failure. Cardiovasc Diabetol. 2018; 17(1): 132. PubMed Abstract | Publisher Full Text | Free Full Text

25. Matsutani D, Sakamoto M, Kayama Y, et al.: Effect of canagliflozin on left ventricular diastolic function in patients with type 2 diabetes. Cardiovasc Diabetol. 2018; 17(1): 73.

PubMed Abstract | Publisher Full Text | Free Full Text

26. F McMurray JJV, Solomon SD, Inzucchi SE, et al.: Dapagliflozin in Patients with Heart Failure and Reduced Ejection Fraction. N Engl J Med. 2019; 381(21): 1995-2008.

PubMed Abstract | Publisher Full Text | F1000 Recommendation

27. Ruberg FL, Grogan M, Hanna M, et al.: Transthyretin Amyloid Cardiomyopathy: JACC State-of-the-Art Review. J Am Coll Cardiol. 2019; 73(22): 2872-2891. PubMed Abstract | Publisher Full Text | Free Full Text

28. González-López E, Gallego-Delgado M, Guzzo-Merello G, et al:: Wild-type transthyretin amyloidosis as a cause of heart failure with preserved ejection fraction. Eur Heart J. 2015; 36(38): 2585-94. PubMed Abstract | Publisher Full Tex

29. Bulawa CE, Connelly S, Devit M, et al.: Tafamidis, a potent and selective transthyretin kinetic stabilizer that inhibits the amyloid cascade. Proc Natl Acad Sci U S A. 2012; 109(24): 9629-34. PubMed Abstract | Publisher Full Text | Free Full Text

30. F Maurer MS, Schwartz JH, Gundapaneni B, et al:: Tafamidis Treatment fo Patients with Transthyretin Amyloid Cardiomyopathy. N Engl J Med. 2018; 379(11): 1007-1016.

PubMed Abstract | Publisher Full Text | F1000 Recommendation

31. Fire A, Xu S, Montgomery MK, et al:: Potent and specific genetic interference by double-stranded RNA in Caenorhabditis elegans. Nature. 1998; 391(6669): 806-11.

PubMed Abstract | Publisher Full Text

32. Coelho T, Adams D, Silva A, et al.: Safety and efficacy of RNAi therapy for transthyretin amyloidosis. N Engl J Med. 2013; 369(9): 819-29. PubMed Abstract | Publisher Full Text

33. F Adams D, Gonzalez-Duarte A, O'Riordan WD, et al:: Patisiran, an RNAi Therapeutic, for Hereditary Transthyretin Amyloidosis. N Engl J Med. 2018; 379(1): 11-21.

PubMed Abstract | Publisher Full Text | F1000 Recommendation

34. Minamisawa M, Claggett B, Adams D, et al.: Association of Patisiran, an RNA Interference Therapeutic, With Regional Left Ventricular Myocardial Strain in Hereditary Transthyretin Amyloidosis: The APOLLO Study. JAMA Cardiol. 2019; 4(5): 466-472.

PubMed Abstract | Publisher Full Text | Free Full Text

35. Solomon SD, Adams D, Kristen A, et al:: Effects of Patisiran, an RNA Interference Therapeutic, on Cardiac Parameters in Patients With Hereditary TransthyretinMediated Amyloidosis. Circulation. 2019; 139(4): 431-443. PubMed Abstract | Publisher Full Tex

36. $\mathrm{F}$ Benson MD, Waddington-Cruz M, Berk JL, et al.: Inotersen Treatment for
Patients with Hereditary Transthyretin Amyloidosis. N Engl J Med. 2018; 379(1): 22-31.

PubMed Abstract | Publisher Full Text | F1000 Recommendation

37. Judge DP, Heitner SB, Falk RH, et al.: Transthyretin Stabilization by AG10 in Symptomatic Transthyretin Amyloid Cardiomyopathy. J Am Coll Cardiol. 2019; 74(3): 285-295

PubMed Abstract | Publisher Full Text

38. Klip IT, Comin-Colet J, Voors AA, et al: Iron deficiency in chronic heart failure: an international pooled analysis. Am Heart J. 2013; 165(4): 575-582.e3. PubMed Abstract | Publisher Full Text

39. Yeo TJ, Yeo PSD, Ching-Chiew Wong R, et al:: Iron deficiency in a multi-ethnic Asian population with and without heart failure: prevalence, clinical correlates, functional significance and prognosis. Eur J Heart Fail. 2014; 16(10): 1125-1132. PubMed Abstract | Publisher Full Text

40. von Haehling S, Gremmler U, Krumm M, et al:: Prevalence and clinical impact of iron deficiency and anaemia among outpatients with chronic heart failure: The PrEP Registry. Clin Res Cardiol. 2017; 106(6): 436-443. PubMed Abstract | Publisher Full Text | Free Full Text

41. Jankowska EA, Rozentryt $P$, Witkowska $A$, et al.: Iron deficiency: an ominous sign in patients with systolic chronic heart failure. Eur Heart J. 2010; 31(15): 1872-80.

PubMed Abstract | Publisher Full Text

42. Martens $\mathrm{P}$, Verbrugge $\mathrm{FH}$, Nijst $\mathrm{P}$, et al:: Limited contractile reserve contributes to poor peak exercise capacity in iron-deficient heart failure. Eur $J$ Heart Fail. 2018; 20(4): 806-808.

PubMed Abstract | Publisher Full Text

43. Tkaczyszyn M, Drozd M, Węgrzynowska-Teodorczyk K, et al.: Depleted iron stores are associated with inspiratory muscle weakness independently of skeletal muscle mass in men with systolic chronic heart failure. $J$ Cachexia Sarcopenia Muscle. 2018; 9(3): 547-556.

PubMed Abstract | Publisher Full Text | Free Full Text

44. Enjuanes C, Klip IT, Bruguera J, et al:: Iron deficiency and health-related quality of life in chronic heart failure: Results from a multicenter European study. Int $J$ Cardiol. 2014; 174(2): 268-75.

PubMed Abstract | Publisher Full Text

45. Melenovsky V, Petrak J, Mracek T, et al.: Myocardial iron content and mitochondrial function in human heart failure: a direct tissue analysis. Eur $\mathrm{J}$ Heart Fail. 2017; 19(4): 522-530.

PubMed Abstract | Publisher Full Text

46. Hoes MF, Grote Beverborg N, Kijlstra JD, et al:: Iron deficiency impairs contractility of human cardiomyocytes through decreased mitochondrial function. Eur J Heart Fail. 2018; 20(5): 910-919.

PubMed Abstract | Publisher Full Text | Free Full Text

47. Haddad S, Wang Y, Galy B, et al.: Iron-regulatory proteins secure iron availability in cardiomyocytes to prevent heart failure. Eur Heart J. 2017; 38(5): 362-372.

PubMed Abstract | Publisher Full Text

48. Jankowska EA, Tkaczyszyn M, Suchocki T, et al:: Effects of intravenous iron therapy in iron-deficient patients with systolic heart failure: A meta-analysis of randomized controlled trials. Eur J Heart Fail. 2016; 18(7): 786-95.

PubMed Abstract | Publisher Full Text

49. van Veldhuisen DJ, Ponikowski P, van der Meer P, et al:: Effect of Ferric Carboxymaltose on Exercise Capacity in Patients With Chronic Heart Failure and Iron Deficiency. Circulation. 2017; 136(15): 1374-1383.

PubMed Abstract | Publisher Full Text | Free Full Text

50. Charles-Edwards G, Amaral N, Sleigh A, et al:: Effect of Iron Isomaltoside on Skeletal Muscle Energetics in Patients With Chronic Heart Failure and Iron Deficiency. Circulation. 2019; 139(21): 2386-2398.

PubMed Abstract | Publisher Full Tex

51. F Lewis GD, Malhotra R, Hernandez AF, et al.: Effect of Oral Iron Repletion on Exercise Capacity in Patients With Heart Failure With Reduced Ejection Fraction and Iron Deficiency: The IRONOUT HF Randomized Clinical Trial. JAMA. 2017; 317(19): 1958-1966.

PubMed Abstract | Publisher Full Text | Free Full Text | F1000 Recommendation

52. Moretti D, Goede JS, Zeder C, et al:: Oral iron supplements increase hepcidin and decrease iron absorption from daily or twice-daily doses in iron-depleted young women. Blood. 2015; 126(17): 1981-9.

PubMed Abstract | Publisher Full Text

53. $\mathrm{F}$ Stoffel NU, Cercamondi $\mathrm{Cl}$, Brittenham $\mathrm{G}$, et al.: Iron absorption from oral iron supplements given on consecutive versus alternate days and as single morning doses versus twice-daily split dosing in iron-depleted women: two open-label, randomised controlled trials. Lancet Haematol. 2017; 4(11): e524-e533. PubMed Abstract | Publisher Full Text | F1000 Recommendation

54. Troughton RW, Frampton CM, Brunner-La Rocca HP, et al:: Effect of B-type natriuretic peptide-guided treatment of chronic heart failure on total mortality and hospitalization: An individual patient meta-analysis. Eur Heart J. 2014; 35(23): 1559-67.

PubMed Abstract | Publisher Full Text | Free Full Text

55. F Felker GM, Anstrom KJ, Adams KF, et al.: Effect of Natriuretic PeptideGuided Therapy on Hospitalization or Cardiovascular Mortality in High-Risk Patients With Heart Failure and Reduced Ejection Fraction: A Randomized Clinical Trial. JAMA. 2017; 318(8): 713-720.

PubMed Abstract | Publisher Full Text | Free Full Text | F1000 Recommendation 
56. Davarzani N, Sanders-van Wijk S, Karel J, et al.: N-Terminal Pro-B-Type Natriuretic Peptide-Guided Therapy in Chronic Heart Failure Reduces Repeated Hospitalizations-Results From TIME-CHF. J Card Fail. 2017; 23(5): 382-389.

PubMed Abstract | Publisher Full Text

57. Yancy CW, Jessup M, Bozkurt B, et al:: 2013 ACCF/AHA guideline for the management of heart failure: a report of the American College of Cardiology Foundation/American Heart Association Task Force on practice guidelines. Circulation. 2013; 128(16): e240-327

PubMed Abstract | Publisher Full Text

58. Ponikowski P, Voors AA, Anker SD, et al.: 2016 ESC Guidelines for the Diagnosis and Treatment of Acute and Chronic Heart Failure. Rev Esp Cardiol (Engl Ed). 2016; 69(12): 1167.

PubMed Abstract | Publisher Full Text

59. F Abraham WT, Adamson PB, Bourge RC, et al:: Wireless pulmonary artery haemodynamic monitoring in chronic heart failure: A randomised controlled trial. Lancet. 2011; 377(9766): 658-66.

PubMed Abstract | Publisher Full Text | F1000 Recommendation

60. Adamson PB, Abraham WT, Bourge RC, et al.: Wireless pulmonary artery pressure monitoring guides management to reduce decompensation in heart failure with preserved ejection fraction. Circ Heart Fail. 2014; 7(6): 935-44. PubMed Abstract | Publisher Full Text

61. Heywood JT, Jermyn R, Shavelle D, et al.: Impact of Practice-Based Management of Pulmonary Artery Pressures in $\mathbf{2 0 0 0}$ Patients Implanted With the CardioMEMS Sensor. Circulation. 2017; 135(16): 1509-1517. PubMed Abstract | Publisher Full Text

62. Abraham J, Bharmi R, Jonsson O, et al:: Association of Ambulatory Hemodynamic Monitoring of Heart Failure With Clinical Outcomes in a Concurrent Matched Cohort Analysis. JAMA Cardiol. 2019; 4(6): 556-563. PubMed Abstract | Publisher Full Text | Free Full Text

63. Costanzo MR, Stevenson LW, Adamson PB, et al.: Interventions Linked to Decreased Heart Failure Hospitalizations During Ambulatory Pulmonary Artery Pressure Monitoring. JACC Heart Fail. 2016; 4(5): 333-44. PubMed Abstract | Publisher Full Text

64. Givertz MM, Stevenson LW, Costanzo MR, et al.: Pulmonary Artery
Pressure-Guided Management of Patients With Heart Failure and Reduced Ejection Fraction. J Am Coll Cardiol. 2017; 70(15): 1875-1886.

PubMed Abstract | Publisher Full Text

65. Jermyn R, Alam A, Kvasic J, et al.: Hemodynamic-guided heart-failure management using a wireless implantable sensor: Infrastructure, methods, and results in a community heart failure disease-management program. Clin Cardiol. 2017; 40(3): 170-176.

PubMed Abstract | Publisher Full Text | Free Full Text

66. Buckley LF, Cooper IM, Navarro-Velez K, et al.: Burden of nursing activities during hemodynamic monitoring of heart failure patients. Heart Lung. 2018 47(4): 304-307.

PubMed Abstract | Publisher Full Text

67. Singh R, Varjabedian L, Kaspar G, et al:: CardioMEMS in a Busy Cardiology Practice: Less than Optimal Implementation of a Valuable Tool to Reduce Heart Failure Readmissions. Cardiol Res Pract. 2018; 2018: 4918757. PubMed Abstract | Publisher Full Text | Free Full Text

68. Sandhu AT, Goldhaber-Fiebert JD, Owens DK, et al:: Cost-Effectiveness of Implantable Pulmonary Artery Pressure Monitoring in Chronic Heart Failure. JACC Heart Fail. 2016; 4(5): 368-75.

PubMed Abstract | Publisher Full Text | Free Full Text

69. Ollendorf DA, Sandhu AT, Pearson SD: CardioMEMS HF for the Management of Heart Failure-Effectiveness and Value. JAMA Intern Med. 2016; 176(10): 1551-1552. PubMed Abstract | Publisher Full Text

70. Veenis JF, Manintveld OC, Constantinescu AA, et al:: Design and rationale of haemodynamic guidance with CardioMEMS in patients with a left ventricular assist device: the HEMO-VAD pilot study. ESC Heart Fail. 2019; 6(1): 194-201. PubMed Abstract | Publisher Full Text | Free Full Text

71. Kilic A, Katz JN, Joseph SM, et al:: Changes in pulmonary artery pressure before and after left ventricular assist device implantation in patients utilizing remote haemodynamic monitoring. ESC Heart Fail. 2019; 6(1): 138-145. PubMed Abstract | Publisher Full Text | Free Full Text

72. Khan Z, Gholkar G, Tolia S, et al: Effect of sacubitril/valsartan on cardiac filling pressures in patients with left ventricular systolic dysfunction. Int $J$ Cardiol. 2018; 271: 169-173.

PubMed Abstract | Publisher Full Tex 


\section{Open Peer Review}

\section{Current Peer Review Status:}

\section{Editorial Note on the Review Process}

Faculty Reviews are review articles written by the prestigious Members of Faculty Opinions. The articles are commissioned and peer reviewed before publication to ensure that the final, published version is comprehensive and accessible. The reviewers who approved the final version are listed with their names and affiliations.

\section{The reviewers who approved this article are:}

\section{Version 1}

\section{Jawahar L Mehta}

Division of Cardiology, Central Arkansas Veterans Healthcare System and the University of Arkansas for Medical Sciences, Arkansas, USA

Competing Interests: No competing interests were disclosed.

\section{Chim C Lang}

Division of Molecular and Clinical Medicine, School of Medicine, University of Dundee, Ninewells Hospital \& Medical School, Dundee, UK

Competing Interests: No competing interests were disclosed.

\section{Ferdinando Iellamo}

${ }^{1}$ Research Institute San Raffaele Pisana, Rome, Italy

2 University of Rome Tor Vergata, Rome, Italy

Competing Interests: No competing interests were disclosed.

The benefits of publishing with F1000Research:

- Your article is published within days, with no editorial bias

- You can publish traditional articles, null/negative results, case reports, data notes and more

- The peer review process is transparent and collaborative

- Your article is indexed in PubMed after passing peer review

- Dedicated customer support at every stage

For pre-submission enquiries, contact research@f1000.com 